Phoebus Athanassiou*

\title{
What's in a Name? Linguistic Diversity, EMU and the Single Currency
}

\begin{abstract}
Linguistic arguments were in some of the new Member States invoked to justify national variations in the spelling of the name of 'euro' while, in others, a 'sovereign right' was claimed to spell that name in accordance with national language rules and usage traditions. Examining these claims against the background of the current Community language rules and of the exceptions and limitations to the 'principle of linguistic equality' inherent in these rules, this article will argue that, while the issue of the spelling of 'euro' is not one of language, even if it were to be conceived as such, the Treaty objectives served by a 'single name for the single currency' should prevail over arguments in favour of national variations of its name.
\end{abstract}

Keywords: linguistic diversity, single currency, Economic and Monetary Union

\section{Introduction and legal framework}

The European Union (EU) is founded on 'unity in diversity': diversity of cultures, national identities and local customs. As language is a fundamental component of national identity, the concern of the EU with the preservation of linguistic diversity represents both a political necessity and a question of principle for the Community Institutions. ${ }^{1}$ The EU's interest in the promotion of linguistic diversity is also intimately linked to the distinct nature of primary and secondary Community legislation and, in particular, to its supremacy over national law ${ }^{2}$

* Scientific Legal Counsel, European Central Bank, Frankfurt am Main, Germany. The views expressed in this article are purely personal and do not represent those of the European Central Bank.

E-mail: phoebus.athanassiou@ecb.int

${ }^{1}$ According to Art. 6 Treaty on European Union, the EU shall 'respect the national identities of its Member States'.

${ }^{2}$ In Case 6/64, Flaminio Costa v E.N.E.L. [1964] European Court Review 585, the European Court of Justice ruled that the signature of the Treaty operated a transfer of Member State powers to the Community that entailed a permanent limitation of their sovereign rights and signalled their commitment to observe Community even against conflicting national laws. 
and to its direct effect, ${ }^{3}$ core features of Community law that cannot assert themselves otherwise than against the background of a fully multilingual EU. ${ }^{4}$ The EU's commitment to linguistic diversity can also be explained in terms of the latter's instrumentality as a legal certainty guarantee: the obligation to draft and present Community legislation in a language that the citizens of Europe can comprehend is so fundamental that the EU's respect for the Member State languages not only serves legal certainty purposes but, ultimately, also contributes to the protection of the rule of law. ${ }^{5}$ Finally, linguistic diversity is rightly deemed to enhance democratic representation, ${ }^{6}$ transparency and accountability by facilitating interaction between the Community Institutions and EU citizens and enabling public access to Community documents. ${ }^{7}$ As a result, linguistic diversity represents one of the most prominent characteristics of the EU as a sui generis 'supranational' organization, distinct from traditional international entities and ordinary federal structures. ${ }^{8}$

Notwithstanding the fact that linguistic diversity is most intimately associated, whether historically, politically or legally with the European integration project, that its importance was already inherent in the text of the Treaties establishing the European Community (the 'Treaty') and the European Atomic Energy

3 The principle entails that, not only Treaty provisions (subject to the conditions stipulated by the European Court of Justice in van Gend \& Loos, ibid), regulations and decisions (pursuant to Art. 249 Treaty on European Community) but also directives can conditionally be invoked by Member State nationals, in their own language, before national courts, as a direct source of rights and obligations that can be enforced against Member States or other individuals.

${ }^{4}$ See Vedaschi, A.: Istituzioni europee e tecnica legislativa. Milano, 2001. 90.

5 The first recital to the preamble to the European Constitution bears an express reference to the rule of law as one of the universal values of Europe's heritage.

${ }^{6}$ See the preamble to the European Constitution thereto, read in conjunction with Art. I-10 (Citizenship of the Union).

7 Under Art. 255 Treaty on European Community, 'Any citizen of the Union ... shall have a right of access to European Parliament, Council and Commission documents'. In the same vein, Art. 21 Treaty on European Community provides that 'Every citizen of the Union may write to [any of the Community Institutions or bodies] in one of the [official languages] and have an answer in the same language.

8 After the 2004 enlargement, the number of the official languages of the Union has reached 20. From 1 January 2007, Irish will also be an official Community language. The planned accession to the EU of Bulgaria and Rumania will bring this figure to 23. By contrast, the UN uses 6 official languages for its intergovernmental meetings and documents while both the Council of Europe, with a current membership of 45, and NATO, with a membership of 26, use English and French only as their official languages. 
Community, ${ }^{9}$ and that the core value attaching to its protection has since been emphasized in the Charter of Fundamental Rights of the European Union (the Charter),${ }^{10}$ in the text of the Treaty establishing a Constitution for Europe (the 'European Constitution') ${ }^{11}$ and, more recently, in a Commission Communication on multilingualism, ${ }^{12}$ even a cursory examination of the Community language rules suffices to reveal the absence of a comprehensive set of provisions dealing with all the different aspects of the interplay between the tasks of the EU, on the one hand, and the role of languages in their performance, on the other, as well as a consistent EU-wide language policy setting out specific standards against which to measure the EU's performance with regard to the use, preservation and promotion of languages. ${ }^{13}$ As a result, the ascertainment of the existence or otherwise of a Community 'principle of linguistic equality' and its precise demarcation are largely questions of interpretation for the Community Institutions, for the Member States and, ultimately, for the European Court of Justice ('ECJ').

Arts 21, 314 and 290 of the Treaty and Regulation No 1/58, as amended by successive Acts of Accession (the Regulation), ${ }^{14}$ set out the legal basis for multilingualism in the EU. ${ }^{15}$ Art. 290 of the Treaty instructs the Council to

9 The reference is to the notion of the 'equal authenticity' of the texts of the Treaties in the official languages of the Member States, enshrined in Arts 314 Treaty on European Community and 225 Euratom, as affirmed by all subsequent Accession Treaties.

${ }^{10}$ According to Art. 22 of the Charter, an important reference document for the interpretation of Community law, '[T]he Union shall respect cultural, religious and linguistic diversity' and in Art. I-3 of the Treaty establishing a Constitution for Europe: '[The Union] shall respect its rich cultural and linguistic diversity, and shall ensure that Europe's cultural heritage is safeguarded and enhanced'.

${ }^{11}$ O. J. C 310, 16. 12. 2004, 1.

12 'A New Framework Strategy for Multilingualism', Commission Communication of 22 November 2005, [COM(2005)596, available at http://europa.eu.int/languages/en/ document/74]. The document reaffirms the Commission's commitment to multilingualism, explores the various aspects of its language related policies and sets out a new framework strategy for multilingualism with proposals for specific actions.

${ }^{13}$ See Shuibhne, N. N.: Does the Draft EU Constitution Contain a Language Policy?, http://www.ciemen.org/mercator/pdf/simp-shuibhne.pdf .

${ }^{14}$ O. J. B $17,6.10 .1958 .385$, as last amended to award to Irish and to three regional languages in Spain a reduced language status

${ }^{15}$ Art. 314 Treaty on European Community provides that 'This Treaty, drawn up in a single original in the Dutch, French, German, and Italian languages, all four texts being equally authentic, shall be deposited in the archives of the Government of the Italian Republic, which shall transmit a certified copy to each of the Governments of the other signatory States. Pursuant to the Accession Treaties, the Danish, English, Finnish, Greek, 
unanimously take decisions on the rules governing the languages of the Community Institutions 'without prejudice to the provisions contained in the Statute of the Court of Justice'. It was on the basis of this Art. that the Regulation was adopted. Besides enumerating, in Art. 1, the official and the working languages of the Community Institutions, the Regulation inter alia provides that a) documents which a Member State or a person subject to the jurisdiction of a Member State sends to the Community Institutions may be drafted in any of the official languages selected by the sender, the reply being drafted in the same language, whereas documents which an institution sends to a Member State or to a person subject to its jurisdiction must be drafted in the language of that Member State (Arts 2 and 3); b) regulations and other documents of general application must be drafted in the 20 official languages (Art. 4); c) the Official Journal of the European Union (the 'Official Journal') must be published in the 20 official languages (Art. 5); d) the Community Institutions may stipulate in their Rules of Procedure (RoP) which of the languages are to be used in specific cases (Art. 6); e) the languages used in the proceedings of ECJ must be laid down in its RoP (Art. 7); f) if a Member State has more than one official language, the language to be used must, at that Member State's request, be governed by the general rules of its law (Art. 8).

The Regulation allows the Community Institutions a fair degree of latitude in the selection of their particular language regime, provided that this is set out in their respective RoP. ${ }^{16}$ Because of this, but also because of the different needs and objectives of the different Community Institutions, the Regulation has been interpreted differently by each of its addressees, as will become apparent later in this paper. Further sources of limitations to the application of the principles of the Regulation, developed later in this paper, are the ECJ

Irish, Portuguese, Spanish and Swedish versions of this Treaty shall also be authentic'. Similarly, Art. 3 of the Treaty of Accession 2003 provides that 'This Treaty, drawn up in a single original in the Czech, Danish, Dutch, English, Estonian, Finnish, French, German, Greek, Hungarian, Irish, Italian, Latvian, Lithuanian, Maltese, Polish, Portuguese, Slovak, Slovenian, Spanish and Swedish languages, the texts in each of these languages being equally authentic, shall be deposited in the archives of the Government of the Italian Republic, which will remit a certified copy to each of the Governments of the other Signatory States'.

${ }^{16}$ It is important to note that the Community Institutions' freedom of choice (a) relates to their working language(s) only; and that (b)it is in all cases subject to the political constraints inherent in selecting one or more languages as their working languages. In the case of the European Central Bank, for instance, its RoP do not expressly identify English as the European Central Bank's working language, in view of the reaction that an explicit reference to that language might perhaps have generated. 
case-law on the Community Institutions' and bodies' language regime and the national choices of Member States with more than one official language.

\section{The spelling of 'euro': A Community competence or a language question?}

\section{A) Background to the debate}

The name of the single currency and of its decimal subdivision ${ }^{17}$ were determined by the Heads of State or Government at the 1995 Madrid European Council meeting. The importance of choosing, before the start of Stage Three of Economic and Monetary Union (EMU), a name for the new currency that would be simple, symbolic and uniform across Member States was acknowledged early on as an essential requirement for a smooth currency changeover and, ultimately, as a determinant of the EMU's public acceptability. ${ }^{18}$

The significance of the name of the single currency was reiterated in Recital 2 of the Council Regulations establishing the legal framework for the introduction of the euro. ${ }^{19}$ The consistent reference in their texts to 'differences in alphabet' suggests that the original intention was not merely to prevent Member States from unilaterally adopting divergent 'national' names for the single currency but, also, to oblige them to uniformly spell 'euro', subject

${ }^{17}$ Although Council Regulation (EC) No 974/98 of 3 May 1998 on the introduction of the euro (O. J. L 139, 11. 5. 1998, 1) requires the same name of the subdivision of the euro to be used in all official languages, written or oral deviations exist in several Member States, including in the case of Greek small denomination coins which, instead of 'EURO CENT', read leptó or leptá (the old 100th part of a drachma) on their national side. Oral deviations can be explained by reference to recital 2 to Council Regulation (EC) No 974/98, inter alia stating that "the definition of the name "cent" does not prevent the use of variants of this term in common usage in the Member States'.

18 'The name of the single currency must be the same in all the official languages of the European Union, taking into account the existence of different alphabets; as of the start of Stage 3, the name given to the European currency shall be euro. This name is meant as a full name, not as a prefix to be attached to the national currency names' (Conclusions of the European Council Meeting in Madrid, at 'I. Economic revitalization of Europe in a Socially Integrated Framework, A. Economic and Monetary Union, I. The scenario for the changeover to the single currency', available at http://europa.eu.int/european_council/ conclusions/index_en.htm).

${ }^{19}$ See Council Regulation (EC) No 1103/97 of 17 June 1997 on certain provisions relating to the introduction of the euro (O. J. L 162, 19. 6. 1997, 1) and Council Regulation (EC) No 974/98. 
nevertheless to the use of a different alphabet in one of the Member States. ${ }^{20}$ Although it is plausible to presume that the legislator's concern was first and foremost with references to the single currency's name in legal texts, there is little to suggest that any formal spelling distinction was ever envisaged between legal documents, on the one hand, and documents intended for the general public, on the other, not least because such a distinction might subvert legal certainty. At the same time, issues relating to the pronunciation of the words 'euro' and 'cent' were presumably not intended to be addressed, if only because to impose specific rules in this respect would lie beyond the remit of the Community. The conclusion that the emphasis was on spelling rather than on pronunciation is also consistent with the Regulation.

Although there is no indication that anything short of the uniform spelling of the name of the single currency was ever intended, at least in official usage, a number of linguistic concerns, initially with regard to the spelling of 'euro' on banknotes and coins, but also in connection with the grammar and formation of plurals of 'euro' as used in other official texts, have been voiced by Member State representations in EU fora ${ }^{21}$ and expressly highlighted in an annex to the European Constitution. ${ }^{22}$ In one Member State ${ }^{23}$ a legal act establishing a 'national' spelling of the name of the single currency was adopted while, in

${ }^{20}$ The reference is to Greece where the name of the single currency is spelt ' $E Y P \Omega$ '. The planned accession to the EU of Bulgaria will signal the inclusion of the Cyrillic alphabet into the 'alphabets officially used in the European Union', as per the Declaration by the Republic of Bulgaria on the use of the Cyrillic alphabet in the European Union to the Treaty concerning the accession of the Republic of Bulgaria and Romania to the European Union (O. J. L 157, 21. 06. 2005, 392).

${ }^{21}$ See, for instance, the ECOFIN meeting of 6 November 2004, held after Member State and EU officials discovered that there had been translation disparities in the spelling of the name of the single currency in several official language versions of the two Council Regulations establishing the framework for the euro and in the text of the 2003 Accession Treaty and of the European Constitution ('euras' in Lithuanian, 'eiro' in Latvian, 'evro' in Slovenian and 'euró' in Hungarian).

${ }^{22}$ The reference is to a declaration by Latvia and Hungary on the spelling of the name of the single currency appended to the European Constitution whereby: 'Without prejudice to the unified spelling of the single currency of the European Union referred to in the Treaty establishing a Constitution for Europe as displayed on the banknotes and on the coins, Latvia and Hungary declare that the spelling of the name of the single currency, including its derivatives as applied throughout the Latvian and Hungarian text of the Treaty establishing a Constitution for Europe, has no effect on the existing rules of the Latvian and the Hungarian languages'.

${ }^{23}$ The reference is to Latvia. 
another three Member States ${ }^{24}$ either a 'national spelling' only is being used in national legal acts or the 'national' and the official spelling are being used interchangeably. Objections to the uniform spelling of the name of the single currency have been expressed in yet another Member State. ${ }^{25}$

Three questions inevitably arise. The first is whether the spelling of 'euro' is a language issue, in which case linguistic and non-discrimination arguments might be of relevance. A second question is whether Member States can legitimately claim a right to spell the name of the single currency in line with their distinct linguistic traditions. A third, and perhaps more fundamental question, is whether convincing arguments can be canvassed against the permissibility of national variations in the spelling of 'euro', on account of the utility of the uniform spelling of the name of the single currency and of the actual existence of several other limitations to the 'principle of linguistic equality', similar in logic to those which this article argues should prevail in connection with the issue of the spelling of 'euro'. The following sections will examine each of these questions in turn.

\section{B) The spelling of 'euro' as a question of language and its link to non- discrimination}

To determine whether or not the issue of the spelling of 'euro' is one of language, in connection with which non-discrimination arguments can legitimately be invoked, we propose to briefly examine the link between the EU's remarkable linguistic diversity and the rationale underlying the EU's concern with nondiscrimination.

An enquiry into the rationale of the regulatory action of the EU in the field of languages suggests that the common thread that runs through all of the relevant Community legal rules, including, in particular, Art. 21 TEC and the provisions of the Regulation, and which informs the policy of the Community Institutions on this question, is the Community's concern to avoid languagebased discriminations against Member State nationals, likely to have an impact

${ }^{24}$ The reference is to Hungary, Lithuania and Slovenia.

${ }^{25}$ The reference is to Malta, where the National Council for the Maltese Language (NCML) recently proposed that the name to be locally used for the single currency should be 'ewro' (report available at: http://www.kunsilltalmalti.gov.mt/filebank/documents/ reportonthenamesoftheeuropeancurrency.pdf). Under Art. 5(2) of the Maltese Language Law, the NCML is the supreme language authority in Malta, with a duty to 'update the orthography of the Maltese language as necessary and, from time to time, establish the correct manner of writing words and phrases which enter the Maltese language from other tongues.' 
on their everyday lives, whether by rendering their access to Community legislation, procedures and information more difficult, or by discouraging language learning and societal linguistic diversity or by subverting the promotion of a thriving, multilingual economy. It follows that, perhaps, the only type of 'discrimination' that one can meaningfully invoke when discussing issues of relevance to the linguistic diversity debate, relates to discrimination which is the result of restrictions likely to adversely affect the ability of the public to interact with the Community Institutions in their mother tongue or to invoke Community legislation or to exercise their citizenship rights and Treaty freedoms. ${ }^{26}$ In this respect, the Community's concern with avoiding language discrimination is no different from its concern with avoiding discrimination on any other grounds.

Turning to the issue of the content of the principle of non-discrimination, it is noted that, while secondary Community law has prohibited both direct and indirect discrimination since the early days of European integration, what it did not expressly do was to provide an actual definition of the underlying concept. ${ }^{27}$ The principle was subsequently elaborated on and applied by the ECJ, notably in the fields of the free movement of labour and occupational gender equality. The gradual expansion of the scope of the Community law prohibition on discrimination continued with the Treaty of Amsterdam, ${ }^{28}$ which considerably broadened the range of prohibited types of discrimination, without, nevertheless, risking a definition of their 'common features'.$^{29}$ Building on the case law of the ECJ and on the progress achieved through the Treaty of Amsterdam, new discrimination-targeted secondary Community legislation has been enacted

\footnotetext{
${ }^{26}$ Particularly as regards the importance of the protection of linguistic rights for the preservation of the free movement of persons, the European Court of Justice has stated that, in the context of a Community based on the principle of the free movement of persons, 'the protection of the linguistic rights and privileges of individuals is of particular importance' (Case 137/84, Mutsch [1985] European Court Review, 2681, at paragraph 11 and Case C-274/96 Bickel and Franz [1998] European Court Review, I-7637, at paragraph 13).

${ }^{27}$ In particular, Council Regulation No. $1612 / 68$ of 15 October 1968 on the free movement of labour within the Community and Council Directive 76/207/EEC of 9 February 1976 on the implementation of the principle of gender equality in relation to access to employment, training, promotion and work conditions.

${ }^{28}$ O. J. C 340, 10. 11. 1997, 1.

${ }^{29}$ Art. 13 of the Treaty of Amsterdam empowers the Community to take action to deal with discrimination based on a whole new range of grounds, including racial or ethnic origin, religion or belief, age, disability and sexual orientation.
} 
in recent years. ${ }^{30}$ However, while the list of non-discrimination grounds is not definitive and notwithstanding that the principle of non-discrimination is likely to be applied, in the future, more broadly, ${ }^{31}$ the fundamental requirements for its ascertainment, namely, the existence of an unlawful differential treatment and the establishment of a prejudice to the legitimate interests of one or more individuals, have, throughout, remained unchanged.

An examination of the 'language issues' that the question of the spelling of the name of the single currency raises and of the alleged discrimination inherent in the Member State obligation to spell its name uniformly, reveals the lack of any relation, direct or indirect, between these and the rationale that underlies the EU's concern with the protection of languages, as a particular aspect of its general non-discrimination policy. This is because the element of 'discrimination' is absent from the equation. It should be remembered that the name of the single currency is an artificial word, selected as a matter of convention in view of its symbolic resonance, which is no more closer to Greek than it is to Hungarian or to any other official language of the Union, in a way such as to suggest a bias in favour of one or more and to the detriment of one or more other official languages and of the Member State nationals that speak them as their native tongues. It was precisely in order to avoid this eventuality that an artificial name, rather than, for instance, one reminiscent of the name of an actual currency, past or present, was eventually retained.

It follows that, because it does not, stricto sensu, raise equal treatment questions, the issue of the spelling of the name of the single currency is not, properly speaking, a language issue in connection with which arguments inspired from the concern with avoiding discrimination against Member State nationals and, more particularly, from the respect of the EU for Member State languages, can legitimately be invoked.

\footnotetext{
${ }^{30}$ These include Council Directive 2000/43/EC of 29 June 2000 on the implementation of the principle of equality without reference to racial or ethnic origin, Council Directive 2000/78/EC of 27 November 2000 on the creation of a general framework for equal treatment in employment and occupation, and Council Directive 2002/73/EC of 23 September 2002 amending Directive 76/207/EEC on the implementation of the principle of gender equality in relation to access to employment, training, promotion and work conditions.

${ }^{31}$ The EU's commitment to the principle of non-discrimination was recently reaffirmed in the Charter which, in Art. 21, prohibits discrimination on the 6 grounds listed in Art. 13 Treaty on European Community, as well as on 7 additional grounds namely, social origin, genetic features, language, political or other opinion, membership of a national minority, property and birth. In common with Art. 12 Treaty on European Community, Art. 21 of the Charter prohibits discrimination on grounds of nationality.
} 


\section{C) EMU and Member State sovereignty}

Even if it were possible to treat the issue of the spelling of the name of the single currency as one of language, so that arguments inspired from the EU's respect for linguistic equality and diversity could legitimately be relied on in support of claims against the uniform spelling of its name, one should not loose sight of the impact on the debate of the 'institutional' aspect of the challenge to the uniform spelling of 'euro', in view of the allocation of competences, in the field of the EMU, between the Community and the Member States.

It should be remembered that, far from simply representing a supranational economic policy co-ordination framework, the EMU is so intimately linked to the European integration project that, Member States have voluntarily agreed to transfer to the Community Institutions and the ECB a host of critical decision-making powers in the areas of economic and monetary policy. While the resulting challenge to the classical notion of national sovereignty is, perhaps, unprecedented, the transfer to the EU level of supreme authority over economic and monetary policy matters has consistently been treated as a sine qua non condition for attaining closer economic and, ultimately, political integration among Member States.

The name of the single currency, while not a monetary or economic policy issue in itself, was the outcome of a political agreement in the field of the EMU, a field of exclusive Community competence under the Treaty. As the exclusive holder of competence in monetary matters, it is only natural that the Community alone should determine the name of the single currency. ${ }^{32}$ Consequently, it cannot be argued that the Council has acted ultra vires and in breach of the principle of subsidiarity in decreeing, through the legal acts establishing the framework for the introduction of the euro, the spelling of the name of the single currency in the languages of the Member States.

It should also be remembered that, pursuant to Art. 5(3) of the Treaty of Accession 2003, ${ }^{33}$ the 'new' Member States are expressly bound to comply, as

${ }^{32}$ This is confirmed by Art. 123(4) Treaty on European Community, according to which the designation of the name of the single currency falls within the sole competence of the EU Council sitting in the composition of the euro area Member States.

${ }^{33}$ This unequivocally provides that: 'The new Member States are in the same situation as the present Member States in respect of declarations or resolutions of, or other positions taken up by, the European Council or the Council and in respect of those concerning the Community or the Union adopted by common agreement of the Member States; they will accordingly observe the principles and guidelines deriving from those declarations, resolutions or other positions and will take such measures as may be necessary to ensure their implementation'. 
a matter of law, with the Madrid European Council political agreement, as this was part and parcel of the acquis communautaire at the time of their accession. An ex post facto challenge to the validity of the European Council decision on the definition of the name of the single currency would therefore be repugnant to the rationale of the sui generis Community legal order ${ }^{34}$ not least because it would be directed against an agreement reached by a body which, albeit not enjoying the status of an Institution, is often considered as a key source of gravitas in the European integration process, responsible for providing 'the Union with the necessary impetus for its development' and for 'defining the general policy guidelines thereof'. ${ }^{35}$

It follows that the 'sovereign right' effectively claimed by some of the Member States to spell the name of the single currency in accordance with their linguistic rules and usage traditions appears to be inconsistent with the exercise by the Community of its exclusive competences in the field of the EMU and, for these reasons, contrary to first principles.

\section{D) Qualifications to the 'principle of linguistic equality'}

A linguistic equality backed challenge to the uniform spelling of the name of the single currency postulates that the 'principle of linguistic equality' has the status of an absolute Community law principle from which no derogation is possible. However, an enquiry into the Community language rules suffices to reveal the existence of a wide range of qualifications to that principle. The origins of these de facto and de jure qualifications can be traced back to a multitude of sources, including primary and secondary Community law, the case law of the ECJ and the CFI and the language regime of the Community Institutions. Taken together, these qualifications suggest not only that there is no absolute 'principle of linguistic equality' within the EU but, more importantly, that, to the extent that such a principle does exist, this is subject to a number of exceptions or restrictions the logic of which is no different in nature to the one which this article suggests should prevail with regard to the issue of the spelling of the name of the single currency. The following

\footnotetext{
${ }^{34}$ In Case 26-62, NV Algemene Transport- en Expeditie Onderneming van Gend \& Loos v Netherlands Inland Revenue Administration [1963] European Court Review 1, [1963] Common Market Law Reiew 105, the European Court of Justice ruled that the Community constitutes a new legal order of international law for the benefit of which the States have limited their sovereign rights, albeit within limited fields'.

${ }^{35}$ Art. 4 Treaty on European Union.
} 
paragraphs will examine each of the principal sources of qualifications to the 'principle of linguistic equality'.

\section{a) Primary and secondary Community law qualifications to 'linguistic equality'}

As we have seen earlier in this paper, the legal basis for the implementation of multilingualism by the Community Institutions is laid down in Arts 21, 314 and 290 TEC and in the provisions of the Regulation.

An enquiry into the Treaty basis for multilingualism and, more particularly, in Art. 21 TEC, reveals the existence of a number of restrictions in the language rules of the EU. Art. $21 \mathrm{TEC}$, the most far reaching of the relevant Treaty provisions, guarantees the right of every EU citizen to write to any of the Community Institutions or bodies in any of the languages stipulated in Art. 314 TEC, receiving an answer in the same language. However, Art. 21 TEC covers written communications only, provided that these have been initiated by a citizen of the EU, thereby excluding from its scope oral and written communications initiated by third country nationals, resident in the EU. Furthermore, Art. 21 TEC refers to Community Institutions only, excluding other Community agencies or bodies from its scope of application. Finally, Art. 21 TEC covers communications initiated from natural persons only, thereby excluding legal persons from its scope of application.

A closer examination of the Regulation, which enumerates the 'official and working' languages of the Community Institutions, guarantees communications between the Community Institutions, the citizens and the Member States in all official languages and stipulates that regulations and other documents of general application must be drafted in all official languages, also reveals the existence of a number of inbuilt qualifications to its principles. Thus, the Regulation refers to the language regime of the Community Institutions only-thereby excluding from its scope of application other EU agencies or bodies-and acknowledges national official languages only-thus excluding from its scope of application regional languages. ${ }^{36}$ Moreover, the Regulation only addresses the written use of languages, offering no guidance in connection with verbal communications between the Community Institutions and the outside world. Last but not least, Art. 6 of the Regulation acknowledges that the Community Institutions have the power to implement their general language regime, in accordance with the principles outlined in the Regulation itself, by stipulating in their Rules of

\footnotetext{
${ }^{36}$ The 'official version' of multilingualism guaranteed by the Regulation has drawn criticism: see Yves, P.: Managing or Celebrating Linguistic Diversity in the EU (2004) http://www.iee.umontreal.ca/pubicationsfr_fichiers/COLLOQUE-2004/IvesIESfinal.pdf.
} 
Procedure (RoP) which of the official languages of the Union are to be used in specific cases, while Art. 8 gives Member States with more than one official national language the choice of deciding whether or not all of these languages will enjoy the status of a 'working' language of the Union, reserving nevertheless for the Council the procedure for their establishment, in accordance with the general rules of the law of the Member State involved.

Taken together, these limitations significantly qualify the claim that the principles enshrined in the Treaty or the Regulation establish an absolute Community 'principle of linguistic equality'.

\section{b) Judicial qualifications to 'linguistic equality'}

The case law of the ECJ and the CFI are similarly inconsistent with the interpretation that the principles enshrined in the Treaty or the Statute establish an absolute Community 'principle of linguistic equality'.

In Kik $v$ OHIM $^{37}$ the Court of First Instance (CFI) held that the language rules laid down in the Regulation do not amount to principles of Community law and do not embody a specific, Community law 'principle of linguistic equality' that cannot legitimately be derogated from: to decide otherwise would be to disregard the character of the Regulation as secondary law. ${ }^{38}$ On appeal, ${ }^{39}$ the ECJ confirmed that Art. 314 TEC does not enshrine an absolute Community law principle of 'equality of languages', adding that even where an individual decision is published in the Official Journal, only the language of the relevant procedure will be authentic and can be used to interpret that decision. ${ }^{40}$ It follows that, because no absolute value attaches to the provisions of Art. 314 TEC, there will be circumstances where documents intended to produce legally binding effects can legitimately be drafted in some of the official languages of the Union only, carrying equal weight and authenticity as

\footnotetext{
${ }^{37}$ Case T-120/99, Kikv Office for Harmonization in the Internal Market (Trade Marks and Designs) (OHIM) [2001] European Court Review II-2235, paragraphs 58 to 59.

${ }^{38}$ This interpretation is consistent with the language of both Art. 290 Treaty on European Community and Art. 6 of the Regulation, of which the former enables the Council to amend the rules governing the languages of the Community Institutions and to establish different language rules as it sees fit, while the latter expressly recognises the Community Institutions' freedom to stipulate in their RoP which of the official languages of the Union will be used in specific cases.

${ }^{39}$ Case C-361/01 P, Christina Kik v Office for Harmonisation in the Internal Market (Trade Marks and Designs) (OHIM) [2003] European Court Review I-08283, paragraph 82.

${ }^{40} \mathrm{Ibid}$, paragraph 87.
} 
tools for the interpretation of legislative intention. ${ }^{41}$ The ECJ further held ${ }^{42}$ that the language regime of an Institution or body will occasionally be the result of a delicate balancing act between conflicting interests, requiring the engineering of linguistically appropriate solutions to practical difficulties, and concluded that the Council's choice, in the case of the OHIM, to treat differently some of the more widely used official languages, was appropriate and proportionate.

In a recent Opinion, ${ }^{43}$ Advocate General Maduro stated that, notwithstanding the fundamental importance of the concept of linguistic diversity and its status as an EU-wide institutional rule, it is impossible to infer the existence of an absolute principle of equality between Member State languages as there will be circumstances, which must nevertheless be 'justified on every occasion' ${ }^{44}$ where this principle will not prevail: 'It is necessary to accept restrictions in practice, in order to reconcile observance of that principle with the imperatives of institutional and administrative life. But those restrictions must be limited and justified. In any event, they cannot undermine the substance of the principle whereby the Community Institutions must respect and use all the official languages of the Union'. ${ }^{45}$ Advocate General Maduro distinguished between (i) communications between the Community Institutions or bodies and citizens of the EU, where the principle of linguistic diversity deserves the highest level of protection and cannot be subject to restrictions resulting from 'technical

\footnotetext{
${ }^{41}$ It is implicit in the European Court of Justice ruling that, while Art. 21 Treaty on European Community embodies a Community law principle (a specific expression of the general principle of equality and non-discrimination on grounds of nationality under Art. 12 Treaty on European Community), Art. 314 Treaty on European Community, to which Art. 21 Treaty on European Community refers, is not a general Community law principle, since the latter's focus is on the protection of the rights of individual citizens while that of Art. 314 is on the duties of the Community Institutions in their external relations or internal operations.

${ }^{42}$ Case C-361/01 P, Christina Kik v Office for Harmonisation in the Internal Market (Trade Marks and Designs) (OHIM) [2003] European Court Review I-08283, paragraphs 92-94.

${ }^{43}$ Opinion of Advocate General Maduro in Case C-160/03 (Spain v Eurojust) of 16. 12. 2004. The Opinion reviews the relevant principles and case-law and is one of the rare occasions where the issue of the languages of the Community Institutions and bodies has been dealt with by the European Court of Justice to such length. In its judgment, delivered on 15 March 2005, the European Court of Justice declared the application for annulment brought by Spain under Art. 230 Treaty on European Community inadmissible and did not, for that reason, examine the issue of the compatibility of the linguistic recruitment requirements of Eurojust with the language regime of the EU.

${ }^{44} \mathrm{Ibid}$. at paragraph 38 .

${ }^{45} \mathrm{Ibid}$. at paragraph 40.
} 
difficulties which an efficient institution can and must surmount'; ${ }^{46}$ (ii) the administrative procedures of Community Institutions or bodies, where 'certain restrictions based on administrative requirements' will be tolerated, as long as the interested parties have been put in a position where they can properly take note of the position of the Institution concerned; ${ }^{47}$ and (iii) rules on the internal functioning of Community Institutions or bodies, where the choice of the language to be used for internal communication 'is the responsibility of those institutions ${ }^{48}$ as long as the basic reasons of administrative efficiency behind a limited number of working languages do not result in an internal language regime that is entirely dissociated from the rules governing the external communication of the Community Institutions or bodies and do not undermine the essence of linguistic diversity.

c) Institutional qualifications to 'linguistic equality'

The discretion that the Regulation grants to the Community Institutions in the application of its principles has led to the establishment of several different working language regimes, one by each of the Community Institutions, designed to reflect their distinct business requirements and external communication needs. These inevitably challenge the linear application by the Community Institutions of the 'principle of linguistic equality'. 49

The European Parliament has repeatedly affirmed its commitment to the pursuit of multilingualism as a condition of democratic representation and as an integral part of European culture, worthy of protection. Its language rules are laid down in Rule 138 of its $\operatorname{RoP}^{50}$ which establishes not one but two distinct regimes, broadly corresponding to the division of the Parliament's work between public deliberations and committee work. Thus, while a fully multilingual regime applies to plenary sessions, multilingualism is less consistently pursued in connection with committee and certain delegation meetings. Given that committee hearings is where most of the preparatory work leading to the adoption of Community legislation takes place, it is possible to treat the provisions of Rule 138 as significant qualifications to Parliament's practice of multilingualism.

${ }^{46} \mathrm{Ibid}$. at paragraph 43.

${ }^{47}$ Ibid. at paragraph 44.

${ }^{48} \mathrm{Ibid}$. at paragraph 46.

${ }^{49}$ For a recent, detailed examination of the application of multilingualism by the Community Institutions and the European Central Bank, see Athanassiou, P.: The application of multilingualism in the European Union Context. European Central Bank Legal Working Paper Series (2006) No. 2, http://www.ecb.int/pub/pdf/scplps/ecblwp2.pdf

${ }^{50} 16^{\text {th }}$ edition, July 2004, available at: http://www2.europarl.eu.int/omk/sipade2? PROG=RULES-EP\&L=EN\&REF=TOC. 
The language regime of the Council is prima facie characterised by the application of full multilingualism, both because the Council represents the interests of Member State governments and because its main function is to adopt legislation. ${ }^{51}$ The language rules of the Council are laid down in Art. 14 of its RoP, ${ }^{52}$ according to which regulations and other documents of general application cannot validly be adopted or enter into force unless drafted in all the official languages of the Union. ${ }^{53}$ However, Art. 14 allows for derogations from the language rules in force, where the Council has unanimously decided to waive their application 'on grounds of urgency'. ${ }^{54}$ Further limitations apply at lower levels within the Council, including within the Committee of Permanent Representatives ${ }^{55}$ and in a number of other Council preparatory bodies. ${ }^{56}$

Except for a few and relatively vague references to 'official', 'working' and 'authentic' languages ${ }^{57}$ the RoP of the Commission ${ }^{58}$ are silent on the issue of its language regime. Notwithstanding the Commission's commitment to multilingualism, as evidenced in its recently adopted Action Plan ${ }^{59}$ and Communi-

${ }^{51}$ Art. 202 Treaty on European Community.

${ }^{52}$ O. J. L 106, 15. 4. 2004, 22.

${ }^{53}$ Under Arts 251 and 252 Treaty on European Community, the same rule applies to Council common positions which cannot be communicated to the Parliament unless adopted in all official languages.

${ }^{54}$ Derogations may be used in the first few months after the accession of new Member State where a revised translation in an official language is difficult to obtain within the specified period. Whenever the Council has recourse to an Art. 14 derogation, its decision is to be recorded in the Council minutes and, where appropriate, the Council should make efforts to thereafter adopt the missing language version(s).

${ }^{55}$ The Comite des Representants Permanents operates on the basis of an informal, mostly trilingual, language regime (English, French and German), although documents submitted to it are occasionally available in other official languages.

${ }^{56}$ Ahead of the 2004 enlargement, the Seville European Council asked the Council to study the question of the use of languages and to consider practical means of improving the situation, without prejudice to basic principles. Further constraints to the provision of full translation and interpretation arrangements have since been introduced to ensure that the Council can cope with post-enlargement demands.

${ }^{57}$ Under Art. 18 of the RoP of the Commission: 'For the purposes of these Rules, "authentic language or languages" means the official languages of the Communities in the case of instruments of general application and the language or languages of those to whom they are addressed in other cases'.

${ }^{58}$ O. J. L 308, 8. 12. 2000. 26.

${ }^{59} \operatorname{COM}(2003) 0449$ final. This was the Commission's response to the December 2001 Parliament resolution referred to above. On 27 July 2003 the Commission adopted its Action Plan 2004-2006 for the promotion of language learning and linguistic diversity. The Action Plan (i) makes concrete proposals for 45 measures to be taken between 2004 
cation, ${ }^{60}$ the most supranational of the Community Institutions has, due to its composition and operational requirements, opted for a more restricted language regime. Thus, while full translation and interpretation are made available in formal occasions and public fora, the de facto working languages of the Commission are limited to English, French and, to a lesser extent, German, also depending on the policy that is being dealt with. This limited working language regime is nevertheless without prejudice to the discharge by the Commission of its legislative initiative tasks in all the official languages of the Union or to the Commission's commitment to practise multilingualism in its external communications. ${ }^{61}$

The language regime of the ECJ differs from that of the other Community Institutions. ${ }^{62}$ Underlying the ECJ's commitment to multilingualism is its concern with providing access to justice and ensuring the effective protection of the rights that individuals derive under Community law. Art. 29 of its RoP provides that the 'language of a case' can be any of the official languages of the EU, including Irish, as determined by the applicant. ${ }^{63}$ In proceedings involving a preliminary ruling, the language of the case is that of the national court or tribunal which has requested the preliminary ruling and is to be used in written

and 2006 with the threefold objective of extending the benefits of language learning to all EU citizens as a lifelong activity, improving the quality of language teaching and building a language-friendly environment in Europe and (ii) proposes a series of actions to be taken at European level with the aim of supporting actions taken by local, regional and national authorities.

${ }^{60}$ See footnote 13 .

${ }^{61}$ See also Principle No 4 of the 'Code of good administrative behaviour for staff of the Commission in their relations with the public' ('Dealing with enquiries'), pursuant to which: 'In accordance with Art. 21 Treaty on European Community establishing the European Community, members of the public who write to the Commission shall receive a reply to letters in the language of the initial letter, provided that it was written in one of the official languages of the Community'.

${ }^{62}$ The sui generis nature of the European Court of Justice's language regime is acknowledged in Arts 290 Treaty on European Community and 7 of the Regulation.

${ }^{63}$ Certain exceptions apply where the defendant is a Member State or a natural or legal person having the nationality of a Member State (the language of the case coincides with the official language of that State; where that State has more than one official language, the applicant may choose between them), where the parties jointly request the use of another official Community language or where a request by one of the parties for the use of another official Community language has exceptionally been granted by the European Court of Justice (on the understanding that such a request cannot be submitted by an Institution). 
and oral pleadings by the parties and in supporting documentation.$^{64}$ However, while the ECJ's judgments are issued in the official languages of the Union, and although Judges and Advocates General may use any language or require the translation of any document into the language of their choice, ${ }^{65}$ internally the ECJ deliberates in French only (this also is the language of its internal administration). The use of a single working language, while no doubt intended to help avoid extensive cross-translation and to ensure the consistent use of vocabulary, represents a notable limitation to the ECJ's practice of multilingualism.

It follows from Art. 24 of the $\mathrm{RoP}^{66}$ of the Court of Auditors that its audit reports and opinions must be made available in all the official languages of the Union when due for publication in the Official Journal of the European Union (OJ). Letters from the President and other observations as well as documents forwarded officially to the Community Institutions or governed by the Staff Regulations are translated into all official languages of the Union, in common with documents intended for general circulation, such as Court of Audit brochures, documents providing information on its work or documents for internal use and circulation to the national audit institutions. However, in common with the ECJ, the dominant internal working language of the Court of Audit is French (although English and German are also used but to a lesser extent).

\section{d) Exceptions to 'linguistic equality' in the case of certain national and} regional Member State languages

Although the official (and, by implication, also the working) languages of the Community Institutions generally coincide with the official languages of the Member States, there are some exceptions to this rule in the case of Member States with more than one official languages. The particular situation of these languages adds a further qualification to the application of the 'principle of linguistic equality' within the EU.

\footnotetext{
${ }^{64}$ It follows from Art. 31 of the European Court of Justice RoP that documents drawn up in the 'language of a case' or in any other language authorised by the European Court of Justice, under Art. 29, are regarded as authentic and cannot be challenged on language grounds.

${ }^{65}$ RoP of the European Court of Justice, Art. 29 (3).

${ }^{66}$ O. J. L 81, 20. 1. 2005. 3.
} 
Irish, the "first" national language of Ireland was, until recently, not recognised as an official Community language,${ }^{68}$ although the Treaties and the European Constitution, ${ }^{69}$ were already drawn up or officially translated into Irish. ${ }^{70}$ The status of the Irish language had originally been determined by an agreement under the terms of which Irish was to enjoy the status of a 'Treaty language', meaning that the Treaties would be officially translated or drawn up in Irish, while Irish would be listed in the Treaties as an authentic language. In this regard, the status of Irish within the EU was unique. Further to Ireland's request in November 2004, the Council unanimously adopted a Council regulation that recognizes Irish as the $21^{\text {st }}$ official Community language from 1 January $2007 .^{71}$ The Community Institutions' obligation to adopt and publish regulations and other documents of general application in Irish is nevertheless subject to a partial ${ }^{72}$ and temporary derogation. ${ }^{73}$

Luxembourgish, Luxembourg's national language ${ }^{74}$ is another example of an official national language which is not an official Community language. However, unlike with Irish, Luxembourgish has never been recognised as an authentic, 'Treaty language'.

Following the accession of Malta to the EU, Maltese, Malta's 'first' national language, ${ }^{75}$ became an official and a working language of the EU.

${ }^{67}$ Under Art. 8 of the Irish Constitution, in the event of a conflict between the Irish and the English language texts of the Constitution, the Irish text prevails.

${ }^{68}$ See Art. 1 of the Regulation which does not include Irish among the official and working languages of the Community Institutions.

${ }^{69}$ The European Constitution formalised the designation of Irish as a Treaty language and, also, changed the existing official and working language dichotomy by introducing a third language designation ('Constitution's languages'-see Art. I-10(2)(d)).

${ }^{70}$ See Arts 53 Treaty on European Union and 314 Treaty on European Community.

${ }^{71}$ See press release for the $2667^{\text {th }}$ session (13 June 2005) by the European Council, General Affairs and External Relations. Council Regulation (EC) No 920/2005, O. J. L 156, 18. 6. 2005. 3.

${ }^{72}$ Under Art. 2 of Council Regulation (EC) No 920/2005 of 13 June 2005 (O. J. L156, 18. 6. 2005. 3.) the derogation does not apply to regulations adopted jointly by the European Parliament and the Council.

${ }^{73}$ Under Art. 2, ibid, the derogation is for a renewable five year period beginning on the day on which the amending Council Regulation applies.

${ }^{74}$ Loi sur les régimes des langues, 1984, Art. 1. Under Luxembourg law, legislation is drafted in French only, although Luxembourgish, alongside French and German, can be used for court proceedings and administrative purposes.

${ }^{75}$ Under Art. 74 of the Maltese Constitution, "(E)very law shall be enacted in both languages and, if there is any conflict between the Maltese and the English texts of any law, the Maltese shall prevail". This rule does not apply to those acts which expressly provide 
However, as it was technically impossible to guarantee the drafting in Maltese of all regulations and other documents of general application adopted by the Community Institutions, a partial ${ }^{76}$ and temporary ${ }^{77}$ derogation similar to the one referred to above in our discussion of the particular situation of Irish, has applied from the Community Institutions' obligation to draft and publish such acts in Maltese.

Turning to the situation of regional languages, the reader will recall that, by acknowledging only national official languages, the Regulation excludes from its scope of application languages enjoying official status in part only of the territory of certain Member States. Considering that, apart from the 20 official Community languages, the number of regional and other 'minority' languages spoken across the territory of the EU exceeds 60 this restriction in the scope of application of the Regulation translates itself into a significant restriction in the scope of application of the 'principle of linguistic equality' itself. The recent recognition by the Council ${ }^{78}$ of the 'semi-official' status of Catalan, ${ }^{79}$ Basque and Galician, in return for the assumption by Spain of the resulting costs, could set a precedent which, if followed, might gradually pave the way for the future use by the Community Institutions of other regional languages. ${ }^{80}$

otherwise, e.g. to the Companies Act, Art. 2(7) of which specifically provides that, in case of conflict, the English language text prevails over the Maltese text. Some secondary legislation is adopted in English only such as, for instance, Central Bank of Malta directives or directives of the Maltese Financial Services Authority. Other legislation in technical areas, such as the Banking Act, the Central Bank of Malta Act or the Companies Act, drafted both in English and Maltese, contain no express provision on which version prevails in case of conflict.

${ }^{76}$ Under Art. 1 of Council Regulation (EC) No 930/2004 (O. J. L 169, 1. 5. 2004), the derogation does not apply to regulations adopted jointly by the European Parliament and the Council.

${ }^{77}$ Arts 1 and 2, ibid, the derogation is for a three year period and can be extended for a further one year period.

${ }^{78}$ See Press Release for the 2667th session (13 June 2005) of the European Council, General Affairs and External Relations.

${ }^{79}$ The particular situation of Catalan, which is spoken by more people than several official Community languages, had already prompted the adoption of the 'Resolution on languages in the Community and the situation of Catalan' (O. J. C 19, 28. 1. 1991. 42).

${ }^{80}$ See Press Release of the Committee of the Regions, 16 November 2005, available at http://europa.eu.int/languages/en/document/81, according to which the Committee of the Regions has recently entered into an agreement with the Spanish Ambassador to the EU approving, for the first time, the use of Spanish regional languages by a Community body. 


\section{The spelling of 'euro': a further legitimate qualification to the 'principle of linguistic equality'}

Our enquiry into the Community language rules and our examination of the language regime of the Community Institutions has revealed the existence of multiple qualifications to multilingualism. The freedom that the Community Institutions enjoy to interpret and adapt the Community language rules in accordance with their distinct needs, the choice that Member States with more than one national official language have to decide which of these will enjoy the status of 'working' languages of the Union and the limited scope of the principle enshrined in the Treaty represent significant qualifications to the general application of multilingualism within the EU. In the same vein, the parallel existence of several language regimes, at different levels and for different purposes, suggests that it is only in connection with their external communication needs that the Community Institutions strictly adhere to multilingualism. ${ }^{81}$ Measured against the background of the absence of a global language-related framework of rules and against the ECJ's acknowledgement that restrictions on linguistic equality can, in appropriate circumstances, be justified, provided that these are based on objective considerations, the abovementioned qualifications inevitably question the extent to which it is possible to speak of a 'linguistic equality principle', in the sense of a fully fledged, firmly entrenched and clearly established Community law principle. One is perhaps safer approaching the debate surrounding multilingualism as one which lends itself more to presumptions than to solid principles.

To the extent, however, that a 'principle of linguistic equality' does exist, it can plausibly be argued that the overriding nature of the common interest in the success of the EMU and the negative impact on the attainment of the

\footnotetext{
${ }^{81}$ Similar considerations also apply to the language regime of the EU agencies and bodies. Thus, while the Regulation establishing the The Office of Harmonistaion for the Internal Market [Council Regulation (EC) No 40/94 of 20 December 1993 on the Community trade mark, O. J. L 11, 14. 1. 1994. 1.] expressly provides in Art. 115 for a specific, limited language regime applicable to the OHIM, the corresponding regulations in the case of other Community agencies, such as the Community Plant Variety Office, the European Agency for Safety and Health at Work, the European Centre for the Development of Vocational Training or the European Environment Agency and the European Environment Information and Observation Network, are either silent on the linguistic issue or expressly provide that the Community agencies to which they relate are subject to the language rules enshrined in the Regulation. The same is also true of some of the more recent Community agencies such as the European Network and Information Society, the European Centre for Disease Prevention and Control or the European Railway Agency.
} 
EMU's objectives resulting from the parallel existence of variations in the name of euro, would suffice to justify reading a further qualification to the application of this principle with regard to the issue of the spelling of the name of the single currency.

It should first of all be remembered that the name of the single currency is an essential part of its definition: in a remarkably simple and straightforward manner, Council Regulation (EC) No 974/98 defines the single currency solely by reference to its name. ${ }^{82}$ As the legal definition of the euro makes no reference to a benchmark against which to establish its exchange value, it follows that the name of the single currency is an indissoluble part of its legal identity that should not be interfered with, even if such name were to be deemed inconsistent with the language rules and traditions of some of the Member States.

Moreover, a multiplicity of spellings in the name of the single currency and the parallel existence of national variations of that name would inevitably subvert the application to the euro, a currency that 'exists simply as a result of a sovereign declaration, ${ }^{83}$ of the principle of monetary nominalism, inherent in Arts 123 and 2 TEC and of Council Regulation (EC) No 1103/97 respectively ${ }^{84}$ and, inevitably, generate uncertainty and confusion in terms of its status as legal tender across the territory of the EU as well as with regard to its singleness.

Perhaps the most decisive justification for opposing variations in the name of the single currency and for rebutting counter-arguments (including those drawn from the EU's respect for linguistic diversity), stems from the importance of the euro as a symbol of the EU. ${ }^{85}$ Over and above its function as a means of payment, the single currency represents a tangible emblem of

\footnotetext{
${ }^{82}$ Art. 2 of the Regulation unequivocally provides that: 'As from 1 January 1999 the currency of the participating Member States shall be the euro. The currency unit shall be one euro. One euro shall be divided into one hundred cent'.

${ }^{83}$ Cabotte, J.-Ch.-Moulin, A.-M.: The Legal Status of the Single Currency. Banque de France Bulletin Digest, 107 (2002), 100. http://www.banque-france.fr/gb/eurosys/ telechar/docs/eurcash3.pdf .

${ }^{84}$ The principle of monetary nominalism is crucial to the rationale for token money, i.e. money without any intrinsic value other than that assigned by the issuing bank. This argument is valid against calls for a differentiation in the spelling of the euro in banknotes and coins where the importance of preserving the highest degree of identity possible between individual examples of the single currency circulating within the EU, would be necessary to achieve fungibility.

${ }^{85}$ Significantly, the European Constitution included, in Art. I-8, the single currency and its name in its exhaustive enumeration of the 'The symbols of the Union'.
} 
the common identity of the Member States and the visible embodiment of their shared commitment to the furtherance of European integration. While national currencies have certainly borne the burden of such symbolism over the centuries, each within the confines of their territory, it is possible to argue that the symbolic charge of the euro by far exceeds that of any other previous currency, since the euro stands not only for a commonly accepted medium of exchange and value but, ultimately, for a symbol of the political and economic communities from which it has sprang and for a portable reminder of a monetary union unprecedented in European history. Thus, if the euro is to fulfil its dual role as a palpable symbol of the Union's shared identity and as a potent integration tool central to the success of the common European project, language-motivated variations in its name should be avoided, not least where legally binding texts are concerned, even if this would mean reading a further qualification to the 'principle of linguistic equality'.

What the qualifications to the 'principle of linguistic equality' examined in this article have in common is the fact that they are underpinned by an objective justification. Such qualifications, particularly as reflected in the language regime of the Community Institutions, agencies or bodies, are almost invariably justified by reference to the need to strike a balance between the EU's respect for linguistic diversity and the inevitable constraints subject to which the Community Institutions operate. Moreover, as we have already seen earlier in this article, both the CFI and the ECJ have ruled that the provisions of the Treaty and of the Regulation that jointly spell out the language regime of the EU do not amount to absolute principles of Community law. Furthermore, both Courts have accepted that there will be circumstances where a restrictive language regime can be adopted by an Institution, provided that this is based on objective and proportional considerations that do not give rise to unwarranted differences of treatment and do not undermine the basic assumptions underlying multilingualism and the Community's commitment to its preservation. Applying mutatis mutandis the reasoning of the Community Courts to the particularities of the EMU, it is submitted that there is little to suggest that the public interest in the success of the EMU and the self-evident importance of the identity of the name of the single currency as a prerequisite for the achievement of the EMU's goals would not qualify as objective considerations of the highest order, justifying a further limitation to linguistic diversity with regard to the question of the spelling of the name of the single currency and legitimizing its uniform spelling, notwithstanding the apparent tension between the EMU's objectives and the language traditions and usages in some of the Member States. 


\section{Conclusions}

The EU's remarkable linguistic pluralism and its respect for linguistic diversity are core features of the Union, intimately related to its unique nature as a sui generis, treaty-based organisation consisting of 25 European countries with distinct, yet closely linked cultural and historical traditions. Despite the EU's promotion of multilingualism and the EU-wide consensus on the cultural and political importance of linguistic diversity, an examination of the Community language rules and of the policy of the Community Institutions in this field reveals that these are subject to several limitations and that multilingualism is not an absolute imperative but, instead, a value that should be balanced against other, equally important, albeit occasionally conflicting values.

The EMU is an area where the Community's policy of respect for multilingualism needs to be balanced against the imperatives of economic and monetary union. Therefore, to treat the question of the spelling of the name of the single currency as a linguistic question, in the context of which language driven considerations need necessarily be attributed a predominant status, would be to loose sight of the status of the actual principle of linguistic equality under Community law and to ignore the fact that, over and above its function as a means of payment, the single currency is also a symbol that must be constant and unchanged across the official Community languages, not least where its use in legally binding texts is concerned, if it is to fulfil its rallying role and integrating mission. 